\title{
Anal Cancer pN1a TNM Finding v8
}

National Cancer Institute

\section{Source}

National Cancer Institute. Anal Cancer pN1a TNM Finding v8. NCI Thesaurus. Code C133783.

Anal cancer with metastasis in inguinal, mesorectal, or internal liac lymph nodes. (from AJCC 8th Ed.) 